\title{
The Search for God and Afterlife in the Age of Science
}

\author{
Ken R. Vincent, Ed.D. \\ Houston, TX
}

\begin{abstract}
Near-death experiences (NDEs) and other transpersonal experiences - those that transcend the usual personal experiential limits of space and/ or time - point to the existence and nature of God and ongoing personal consciousness following physical death. In this article, I review the history of these experiences prior to 1850 and of their study during three periods of scientific research between 1850 and the present. I conclude that (1) a large percentage of the population has experienced NDEs and other transpersonal experiences, (2) the overwhelming majority of these experiencers are mentally healthy, and (3) these experiences change people's lives for the better. I contend that although NDEs and other transpersonal experiences cannot prove the existence of a personal God and afterlife, they definitely point to them.
\end{abstract}

KEY WORDS: near-death experience; transpersonal; mysticism; God; afterlife.

Transpersonal experiences involve perceptions that transcend the usual personal limits of space and/or time. Also known as "mystical experiences," "religious experiences," or "spiritual experiences," transpersonal experiences include: direct communication of humans with God or other divine beings, near-death experiences (NDEs), deathbed visions (DBVs), and after-death communications (ADCs). Individuals who restrict their study of transpersonal experiences to NDEs sometimes call other transpersonal experiences "near-deathlike experiences" or, more awkwardly, "a near-death experience in

Ken R. Vincent, Ed.D., is a retired Professor of Psychology, Houston Community College-Northwest College. This article is an updated version of a paper presented at the 2006 conference of the International Association for Near-Death Studies at The University of Texas M. D. Anderson Cancer Center, Houston, Texas. Correspondence regarding this article should be sent to Dr. Vincent at 1701 Hermann Dr. \#904, Houston, TX 77004; e-mail: professorvincent@yahoo.com. 
which the person didn't die." Unlike parapsychologists, who try to explain paranormal phenomena, transpersonal psychologists focus on the anomalous experiences of non-psychotic individuals and the effects of these experiences on them.

By their nature, many transpersonal experiences point to the existence and nature of both God and an afterlife of continued personal consciousness beyond physical death. Scientific study of "transpersonal experiences" developed between the second half of the $19^{\text {th }}$ century and the present (Basford, 1990, pp. viii-ix). Whereas William James coined the term "transpersonal experience," Abraham Maslow greatly expanded the serious study of transpersonal experiences by deeming transpersonal psychology a "fourth force" in psychology after psychoanalysis, behaviorism, and humanism (Daniels, 2004, pp. 366-370).

In this paper, I will not address transpersonal experiences involving mediums, nor will I address faith healing, because I have not researched those areas. Rather, my focus will be the development of the study of near-death and near-death-like experiences over the past 150 years. I begin with a brief discussion of transpersonal experiences prior to the mid- $19^{\text {th }}$ century.

\section{Transpersonal Experiences Prior to 1850}

All of human history is testimony to humanity's experience of the transpersonal. Prior to research into transpersonal experiences by biomedical researchers and social scientists, these accounts were often anecdotal and frequently "much-told tales." Twenty-five hundred years ago, Plato recorded the NDE of Er in his Republic (Plato, $4^{\text {th }}$ century BC/1892). First-hand accounts from credible sources in the ancient world are rare. Zoroaster composed a poem that documented his direct experience of God (Vincent, 1999, pp. 91-127). St. Paul also told in his own writings of his life-transforming ADC of Jesus (I Cor 15:5-8). Additionally, St. Paul told of his out-of-body experience in which he was transported to the third level of Heaven (II Cor 12:2-5).

In the $6^{\text {th }}$ century, St. Gregory the Great in Book 4 of his Dialogues (Gregory, $6^{\text {th }}$ century $\mathrm{AD} / 1959$ ) provided a treasure-trove of transpersonal experiences including NDEs, ADCs, DBVs, and vivid dreams. These and other examples from ancient and medieval literature have some validity by the very fact that they sound so similar to modern transpersonal accounts; however, in almost all cases there is simply not 
enough in the ancient record to make a judgment on the veracity of the story. In her analysis of medieval and modern accounts of otherworld journeys, Carol Zaleski (1987) noted, "we cannot simply peel away the literary wrapper and put our hand on an unembellished event, even when a vision actually did occur, it is likely to have been re-worked many times before being recorded" (pp. 86-88). She suggested, for example, that the Church would have been eager to insure that recorded accounts did not contradict "Truth" as defined by Church doctrine. Nevertheless, in the medieval world, first-hand accounts of transpersonal experiences became more commonly reported in the lives of the saints. A modern interdisciplinary collaboration between a historian and a psychiatrist into medieval transpersonal experiences revealed that visions appeared to have been related to mental illness in only 4 of the 134 cases the authors studied (Kroll \& Bachrach, 1982).

\section{First Period of Scientific Research into Transpersonal Experiences (1850s-1920s)}

In the mid- $19^{\text {th }}$ century, medicine was becoming a science. Physicians were rapidly learning about the human body, discovering that many of their long-revered treatments and medications were ineffective and/or toxic (Benson \& Stark, 1997, pp. 109-114). Social sciences became a reality in large part due to the invention of modern statistics (Wood \& Wood, 1996, p. 23). Concurrently, comparative religion emerged as a topic of study for the first time in the West since the classical period (Nigosian, 2000, pp. 412-413). This period witnessed the publication of Max Müller's Sacred Books of the East (1897) that enhanced Western knowledge of Eastern religion. Simultaneously, archeology was changing from a "treasure hunt" for adventurers into a methodical science (Oakes \& Gahlin, 2003, pp. 26-41).

During this same era, physicians began to report DBVs and the rarer NDEs in their medical journals (Basford, 1990, pp. 5-10, 131-137; Walker \& Serdahely, 1990, p. 108). Aided by social scientists, case studies and observations of transpersonal experiences began to be verified. In the 1880s, the Society for Psychical Research was formed in England, and shortly thereafter, the American Society for Psychical Research was founded (Cardeña, Lynn, \& Krippner, 2000, p. 6). The membership of these bodies largely consisted of physicians, professors, and preachers. Its members were interested in interviewing subjects 
and assessing the credibility of case studies involving transpersonal experiences.

Groundbreaking studies produced by this new group of psychical researchers included Frederick Myers's Human Personality and its Survival of Bodily Death (1903) and Sir William Barrett's Deathbed Visions (1926). The following veridical account taken from Myers's classic work documents the infrequent phenomena of physical contact with a vision. It is the case of an appearance to Baron Basil Fredorovich von Driesen of his dead father-in-law with whom he had not been on good terms. The purpose of the father-in-law's ADC was reconciliation. Basil reported shaking the apparition's hand, which he described as "long and cold," after which the vision disappeared. The next day after the church service, the priest told Basil and his wife, "This night at 3:00, Nicholas Ivanovitch Ponomareff appeared to me and begged me to reconcile him to you." Thus, on the same night the son-in-law and the priest, at separate locations, saw a vision of the same dead man (Myers, 1903, pp. 40-42).

Another important study in the $19^{\text {th }}$ century was Henry Sidgwick's Report on the Census of Hallucinations (Basford, 1990, p. 161). The British study included over 15,000 non-psychotic people and found roughly $10 \%$ of the participants reported apparitions, including ADCs and religious visions. This was also the case in a 1990s replication of the study using a representative sample of over 18,000 participants (Bentall, 2000, pp. 94-95). Although people with schizophrenia can and do report mystical experiences along with their psychosis (Siglag, 1986), more often than not people without mental illness report seeing religious figures whereas people with schizophrenia report being religious figures.

James Hyslop wrote many books on transpersonal experiences. His Psychical Research and the Resurrection (1908) is interesting. It includes not only veridical examples of $\mathrm{ADCs}$ and DBVs but also a treatise on the resurrection as an $\mathrm{ADC}$ in which Hyslop stated that "the existence of veridical apparitions would substantiate all that is useful in the story of the resurrection and make human experience in all ages akin" (p. 383). This same approach, emphasizing that Jesus's resurrected body was (quoting St. Paul) a "spiritual" body (Hyslop, 1908, p. 377), was taken at mid-century by the Anglican Canon Michael Perry, who wrote The Easter Enigma: An Essay on the Resurrection with Specific Reference to the Data of Psychical Research (1959). At the end of the $20^{\text {th }}$ century, Phillip Wiebe again raised this 
thesis in his book, Visions of Jesus (1997). These and other modern authors made the case that post-resurrection appearances of Jesus are visionary experiences indistinguishable from ADC reports throughout history (Hick, 1993, pp. 41-44; Maxwell \& Tschudin, 1990, pp. 66-67, $78,105,119,150,166,168$; Wiebe 1997, pp. 3-88).

The premier publication of the first period of research into transpersonal experiences was William James's The Varieties of Religious Experience published in 1902. In it, he boldly stated,

In one sense the personal religion [currently termed transpersonal or spiritual] will prove itself more fundamental than either theology or ecclesiasticism. Churches, when once established, live at second-hand upon tradition; but the founders of every church owed their power originally to the fact of their direct personal communication with the Divine. Not only the superhuman founders, the Christ, the Buddha, Mahomet, but all the originators of Christian sects, have been in this case; - so personal religion should still seem the primordial thing, even to those who continue to esteem it incomplete (James, 1902/ 1994, pp. 35-36; bracketed material added).

He went on to state that,

the difference in the natural 'fact' which most of us would assign as the first difference which the existence of a God ought to make would, I imagine, be personal immortality. Religion, in fact, for the great majority of our own race means immortality, and nothing else (James, 1902/1994, p. 569).

Further validation for James's assertion that the founders of every religion obtained the spiritual knowledge from direct transpersonal experiences of God can be found in Christopher Partridge's (2004, pp. 14-24) New Religions. Partridge listed over 200 religions that were founded or came to prominence in the last century; virtually all of their founders were transformed and inspired by a transpersonal experience such as a voice, a vision or other mystical experience of God, or an ADC from a religious figure.

\section{Intermediate Period (1930s-1950s) and Second Period (1960s to Present) of Scientific Research into Transpersonal Experiences}

During the 1920's, research into transpersonal experiences began to wane. In my opinion, possible reasons for this include the death of the founders of research into transpersonal experience, the rise of atheism 
and Marxism culturally, and Freudianism and behaviorism in the social and biomedical sciences. In an article focusing exclusively on NDEs, Barbara Walker and William J. Serdahely (1990) noted the same "dry" period. Carl Jung (1961) became a lone "voice in the wilderness" regarding the importance of religious and spiritual experience in healthy human functioning.

As the father of humanistic psychology, Maslow revolutionized the study of psychology by emphasizing the healthy personality rather than psychopathology. Toward the end of his life in the 1960s, he went beyond this innovation by resurrecting James's term "transpersonal" and founding the field of transpersonal psychology (Maslow, 1964, pp. $\mathrm{x}-\mathrm{xi}, 19-29$; Partridge, 2004, pp. 366-370). During this same period, scientists had begun to use the electroencephalogram (EEG) to study meditation and other altered states of consciousness, demonstrating that meditative states were physiologically different from ordinary consciousness and not merely the "wishful thinking" of believers (Wulff, 1997, pp. 69-89, 95-116). Concurrently, the facilitation of religious experience using psychedelic drugs became the object of scientific study.

Timothy Leary was a respected professor of psychology at Harvard and one of the world's foremost researchers on personality at the time he began to experiment with LSD and other psychedelic drugs (Smith, 2000, p. 6). He did so in the best of company - with Huston Smith, a Methodist minister, theologian, and researcher on comparative religion, and Aldous Huxley, author of Brave New World and The Doors of Perception (Smith, 2000, p. 6). One of Leary's early research projects at Harvard was nicknamed his "Prisoners to Prophets" program (Leary, 1983, pp. 83-90). In this study, he supervised the administration of LSD to prisoners whose progress he then followed after their release from jail. Initially, the LSD group had a lower recidivism rate than those in the control group who had not received psychedelic drugs. However, later these results were questioned, and it was suggested that the seeming success of the study could be better attributed to the interaction of the students with the prisoners, helping them readjust to society and helping them find jobs. In fact, a 34-year follow-up showed recidivism to be slightly higher for the LSD group (Horgan, 2003).

Leary sincerely thought he had discovered something beneficial to society: a shortcut that would enable everyone to become a mystic. Thus he was for some time the champion of psychedelic drugs. He and 
his sophisticated friends did not have negative experiences with LSD, and some had gleaned insights under its influence. Leary thought that the mystical experience was caused by the drug; sadly, the causality and dynamics of such experiences turned out not to be that simple.

I was an undergraduate student in psychology at the time this initial research was being carried out. One day, one of my professors came into class and announced that he was doing LSD research, and he wanted us all to take the drug as a part of his experiment. Now, this was in the days prior to strict guidelines for ethical research on human subjects, and it was not uncommon for professors to include among course requirements that students participate in their experiments. I was much relieved when my professor said that if we had jobs, we were not required to participate. He then went on to tell us that this stuff was SO good that he would give us some if we came to his office after class! He did caution that if we took it on our own, we had to promise to take it with a friend, as there were a few people who had "unusual side-effects." A few years later, after a number of people had experienced what came to be known as "bad trips," the Federal Government made psychedelics illegal. Clearly, the experience of God was not IN the drugs, as Leary had hoped.

About this time, a Harvard researcher named Walter Pahnke (Argyle, 2000, pp. 64-66; Smith, 2000, pp. 199-205) conducted a controlled experiment at Andover Theological Seminary in which he divided seminarians into two groups: The members of one group took psychedelics, and those of the other took a placebo. He then put both groups into a $2 \frac{1}{2}$-hour Easter Service. The result was that a significant number of those who received the psilocybin reported mystical experiences compared to the control group. What Pahnke had done was what shamans have done for centuries: use drugs to get their subjects "off-center." Psychedelic drugs induce perceptual distortions and force the subject out of one's normal mind-set, but it is the shaman - or, in the case of Pahnke's experiment, the Christian ministers - who plays the critical role of guiding the experiencer. In the case of Native American shamans, the setting is a hogan where the participant is surrounded by fellow worshipers, fire, and chanting. In the Christian Easter service, the "Christian shamans" provided the context of music, liturgy, and prayer. The total spiritual setting is the "trigger" of the mystical experience; the drugs aid only to the extent that they allow the experiencer to step out of ordinary reality (Wulff, 1997, pp. 188- 
193). As Sufi mystic Abu Said (Vincent, 1994, p. 40) put it, "The way to God is but one step, the step outside yourself."

In addition to the relationship between transpersonal experiences and psychedelic drugs, there is also some overlap between transpersonal experiences and psychosis. This topic was the focus of a recent book entitled Psychosis and Spirituality (Clarke, 2001). Mysticism can be differentiated from psychosis through psychological assessment. Ralph Hood (2001, pp. 20-31) developed two scales to measure the nature and depth of religious mystical experience: the Religious Experience Episode Measure (REEM) and the Mysticism Scale (MScale). These instruments separate mystics from non-mystics but do not clearly differentiate mystics from psychotics. To achieve the latter, a diagnostician needs also to use an instrument that differentiates people with and without psychosis. Use of more than one test for differential diagnosis is commonplace in psychology; for example, the diagnosis of learning disability requires administration of both reading and IQ assessments (Vincent, 1987, pp. 45-58).

Although it is possible to be both mystic and psychotic, modern research has uncovered many more people having mystical experiences than having psychoses (Argyle, 2000, pp. 71-72, Hood, 2001, pp. 410-411). These differences are further highlighted in a study using word analysis to differentiate the verbal descriptions of mystics, psychedelic drug users, psychotics, and people not included in any of those groups. The researchers found that the descriptions of the various experiences do not match (Oxman, Rosenberg, Schnurr, Tucker, \& Gala, 1988). In general, studies on mysticism and mental health have consistently shown that the overwhelming majority of mystics are mentally "normal" or "healthy."

In 1969, Sir Alister Hardy, a biologist, set up the Religious Experience Research Unit at Oxford University, now the Religious Experience Research Centre at the University of Wales, Lampeter (Rankin, 2008, p. 3). This venture marked the beginning of large-scale research into mystical experiences. In order to research these experience within the general population, Hardy made an appeal to the general public through newspapers and pamphlets with the question, "Have you ever been aware of or influenced by a presence or power, whether you call it 'God' or not, which is different from your everyday self?" He invited readers to send in their responses. Ten years later, Hardy (1979/1997) published a book based on the first 3,000 responses he had received to this question on mystical experiences. 
Next, moving beyond self-selected sample methodology, researchers undertook large-scale survey research. In 1977, David Hay and Ann Morisy (Hardy, 1979/1997, pp. 124-130) asked the same question to a British national sample of 1,865 persons: $35 \%$ responded "yes." Between the times of the appeal in the British newspaper and the objective largescale population survey, Andrew Greeley (1974) and his colleagues at the National Opinion Research Center at the University of Chicago began asking a very similar question: "Have you ever felt as though you were very close to a powerful spiritual force that seemed to lift you out of yourself?" A sample of 1,467 Americans showed 39\% answered "yes." Over the years, repeated national samples have shown that the number of people responding affirmatively to this question has ranged from $35 \%$ to $50 \%$ (Wood, 1989, p. 856). When respondents have been interviewed rather than surveyed, the number has increased to over 60\% (Hay, 1987, pp. 136-137).

Possibly because more Americans are feeling more confident in their spirituality, or maybe because the question was phrased differently, when asked recently, "In general, how often would you say you had experienced God's presence or a spiritual force that felt very close to you?", 86\% of Americans reported one or more transpersonal experiences. Who knows? Maybe we humans are coming "out of our (spiritual) closet" (Mitofsky International and Edison Media Research, 2002)!

In the first 3,000 cases of mystical experiences that Hardy and his colleagues collected, one of the "triggers" of mystical experience "was the prospect of death." More recently, Mark Fox (2003, pp. 243-329) has analyzed these "crisis experiences" (CEs) and compared them to other non-crisis mystical experiences (non-CEs). Whereas most of these CEs were NDEs, it was hard to tell from the voluntary reports whether or not these individuals had died or, in some cases, only had come close to death. In spite of this limitation, Fox conducted the study because these CE/NDEs had occurred prior to the popularization of the NDE. He found remarkable similarity between these two groups. In other words, one of the ways to have a mystical experience is to die! This link between the NDE and other mystical experiences is a commonly reported finding (Cressy, 1994, 1996; Fenwick \& Fenwick, 1995, pp. 229-236; Kircher, 1995, pp. 81-91; Ring, 2005, pp. 51-52; Vincent, 1994, pp. 9-17).

Recently, Xinzhong Yao and Paul Badham of the Alister Hardy Research Centre have published a major research project entitled 
Religious Experience in Contemporary China (2007). Yao and Badham surveyed 3,196 Chinese. Religion is suppressed in China, and it should be no surprise that few respondents indicated a religious affiliation, but $56.7 \%$ reported religious/spiritual experiences. Using Buddhism as an example, only $2.3 \%$ of the Chinese reported being Buddhist, but 27.4\% said they had worshiped Buddha within the past year, and $18.2 \%$ reported a religious experience involving Buddha or bodhisattvas at some time during their lives (Holmes, 2006).

Another major cross-cultural study on transpersonal experiences is reported in Osis and Haraldsson's book, At the Hour of Death (1977), in which they documented 1,708 cases of deathbed visions that physicians and nurses in the United States and India had recorded. These researchers compared patients with deathbed visions to patients whose diagnosis would have resulted in psychotic hallucinations such as brain disease, uremia, and fever in excess of 103 degrees Fahrenheit. They also took medication effects into account. The apparitions of the dying in both the U.S. and India involved dead relatives and religious figures; in no case, in either the U.S. pilot study or the cross-cultural study, was the "take-away" person - the relative or religious figure whom the patient perceived had come to take the patient to the afterlife - an apparition of a living individual. In general, deathbed visions were similar in both countries, though there were some differences. One-tenth of the Americans and one-third of the Indians expressed negative emotions when religious figures appeared. Indians were more anxious about dying, probably because the Hindu religion teaches Judgment. However, once the dying experience began, it was almost always pleasant for both Indians and Americans. The only report of a person going to Hell was that of an Italian American woman. The most striking difference between deathbed experiences in the U.S. and India is one that could have been anticipated: The religious figures that came to take the person into the afterlife corresponded to the person's religion. Christians saw God, Jesus, angels, and Mary. Hindus saw such figures as Yamaraj, the Hindu god of death, as well as Krishna, Rama, and Durga, (Osis \& Haraldsson, 1977, pp. 52-78, 218).

A byproduct of the Osis and Haraldsson study was that it included 120 people who were near-death experiencers (NDErs). Like the deathbed visioners, the NDErs in India and the U.S. had similar experiences. The one exception was that in the U.S., people reported being told to return or that they "had work to do." In India, they were 
apt to be told that their name was "not on the list." In one case, the Hindu NDEr reported that a Hindu messenger of death told him they had brought the wrong person. Interestingly, this report included an account in which another man of the same name was in the same hospital, and when the initial patient regained consciousness, the other man with the same name died (Osis \& Haraldsson, 1977, pp. 147-159).

Also in the 1970s, mental health professionals undertook research to objectify psychiatric diagnosis. In 1980, the results of this research culminated in the Diagnostic and Statistical Manual of Mental Disorders III (DSM-III). I was privileged to work on this project (American Psychiatric Association, 1980, p. 481). The DSM-III removed Freudian mythology from the diagnostic nomenclature and forbade a diagnostician to jump to a diagnosis based on a single symptom like hallucinations. More importantly, it acknowledged that religious experience was not in itself pathological; in other words, it was now OK for God to talk to you!

In 1975, Raymond Moody published Life After Life and coined the term "near-death experience." Immediately after this publication, serious research into the NDE began. The International Association for Near-Death Studies (IANDS) was founded in November, 1977, by Raymond Moody, Kenneth Ring, Bruce Greyson, Michael Sabom, John Audette, and a few others (International Association for Near-Death Studies, 2009). Research into the NDE quickly captured the attention of the public, overshadowing all other transpersonal experiences. This conclusion is evidenced by the sheer volume of NDE research (Holden, Greyson, \& James, 2009, pp. 1-10). Highlights of serious research into NDEs include Ring's first objective analysis of NDE characteristics (1980). Shortly thereafter, Sabom (1982) carried out the first prospective study on the NDE. Ring and Sharon Cooper recently researched what the blind "see" when they have an NDE (Ring \& Valarino, 1998, pp. 73-95). More recently, Jeffery Long and Paul Perry (2010) have published an analysis of 613 cases from Jeff and Jody Long's Near-Death Experience Research Foundation (NDERF) Web site. One fruitful area of research has been into the aftereffects of NDEs and other transpersonal experiences. Briefly, the effects are overwhelmingly positive and life-changing, and they do not fade over time (Hay, 1987, pp. 153-167; Ring \& Valarino 1998, pp. 123-144).

As questions have been raised regarding the NDE and its characteristics, scientific research has attempted to deal with them. 
For example, when the press consistently claimed that all NDEs were pleasurable experiences dominated by feelings such as peace, love, and joy, Greyson and Nancy Evans Bush (1992), in their article "Distressing Near-Death Experiences," countered with their analysis of experiences dominated by feelings such as isolation, torment, or guilt. When the astronomer Carl Sagan, acting as an arm-chair psychoanalyst, made the claim that NDEs were just people reliving their birth experiences, his "theory" was soon refuted in an article by Carl Becker that included data on not only newborn physiology but also the lack of similarity between features of the NDE and birth (Becker, 1982). In a study by Susan Blackmore (1983) entitled "Birth and OBE," she found no difference in reports of passing through a tunnel as a transition into another reality for persons born by Caesarean section or delivered vaginally. Finally, although the majority of NDEs are pleasurable, the process of birth is widely acknowledged to be traumatic. In all of recorded history, only one person is said to have laughed instead of crying at birth: Zoroaster (Vincent, 1999, p. 3). Sagan has not been the only skeptic of the NDE, but his case does illustrate that when questions are raised, scientific investigation follows. "Explanatory Models for Near-Death Experiences" by Greyson, Kelly, and Kelly (2009, pp. 213-234) provides an excellent overview of research supporting and refuting claims about the origins of NDEs.

Michael Persinger offered more than theories on the NDE and other transpersonal phenomena (Kelly, Greyson, \& Kelly, 2007, pp. 382383). Using electromagnetic stimulation, he attempted to create NDEtype phenomena in the laboratory, and some of his subjects reported bits and pieces of phenomena similar to the NDE and other transpersonal experiences as well as extraneous phenomena such as dizziness and tingling (Greyson, 2000, p. 335). However, a recent Scandinavian study failed to replicate his findings (Keller, 2005). Based on Persinger's research, his student, Todd Murphy (2006), began marketing electronic devices to enhance meditative experiences. If transpersonal experiences could be safely induced in the laboratory using electrical stimulation, would this ability fulfill the age-old dream of giving everyone a mystical experience, change people for the better, and bring about a "new age?" On another note, Persinger expressed the belief that his research demonstrates that the NDE and other transpersonal experiences are located within the brain (Kelly, Greyson, \& Kelly, 2007, pp. 382-384). However, brain 
stimulation can be interpreted as "cleansing the doors of perception" and leading to illumination (Kelly, 2007, pp. 603-607).

Since ancient times, people have attempted to induce transpersonal experiences. In the ancient world people used initiation into the "mysteries" (Meyer, 1987, pp. 3-13). Regarding the induction into the Mysteries of Isis, Apuleius gave an account that is in all probability autobiographical:

I approached the confines of death. I trod the threshold of Prosperine: and born through the elements I returned. At midnight I saw the sun shining in all its glory. I approached the gods below and the gods above, and I stood beside them, and I worshipped them. (Meyer, 1989, p. 199).

He went on to state that he could not reveal more because it was a mystery! Historians have not established what percentage of people in the ancient world was able to have an induced transpersonal experience. The ancients' methods also are not known, but the idea that they had such knowledge continues to be intriguing (Ring, 1986).

In one attempt at induction, Moody invented the psychomanteum to facilitate $\mathrm{ADCs}$ in a non-intrusive way. Using a slightly tilted mirror, low light, a soft chair, and a dark room, Moody was able to create the condition for about half of his subjects to experience visits from their dead loved ones (Moody \& Perry, 1993). This experiment has been replicated several times (Hastings et al., 2002; Roll, 2004). I am not alone among my colleagues in feeling that this modern-day necromancy is not without risks. If these visions are indeed real, as Moody noted (1993, p. 112), the people who show up may not be the ones hoped for; if the apparitions are the products of the subject's unconscious mind, it is probably best to leave them undisturbed.

This brings us to another aspect of NDE research: religion and NDEs. Fox (2003, pp. 55-97) saw a deafening silence among theologians, who generally have not tackled the topic. This omission seems to be true for theologians in Christianity as well as other religions. However, Judith Cressy (1994), a minister and doctorally trained pastoral counselor, wrote linking the commonalities between NDEs and mysticism. Liberal Christian theologian Marcus Borg (1997, pp. 37-44, 171) has supported the validity of transpersonal experiences; he has also voiced tentative optimism about the validity of NDEs. John Hick, the world's foremost Universalist/Pluralist Christian theologian, is an enthusiastic endorser of transpersonal 
experiences and tentatively hopeful of the veracity of NDEs (Hick, 1999). Canadian theologian Tom Harpur has also addressed how multiple aspects of NDEs relate to Christianity in general, to specific Christian sects, and to world religion. He concluded his book Life After Death (1991) with a strong statement relating NDEs to Christian Universalist theology.

Outside of Christianity, endorsement for NDEs' relevance to religion is sparse. Some years ago, I was watching a television program in which the Dalai Lama was asked how NDEs affected his belief in reincarnation. He replied that NDEs reflect the "Bardo" state - in Buddhist theology, the intermediate state between death and rebirth. Recently, Zoroastrian priest Kersey Antia (2005) has written about Zoroastrianism, NDEs, and other transpersonal experiences. Writers on comparative religion have also written on the NDE. Zalesky's (1987) Other World Journeys: Accounts of Near-Death Experience in Medieval and Modern Times, Farnaz Masumian's (1995) Life After Death: A Study of The Afterlife in World Religions, and Gracia Fay Ellwood's (2001) The Uttermost Deep are good examples of books on NDEs and comparative religion. Recently, Gregory Shushan (2009) examined five ancient and culturally independent civilizations and concluded that the core elements of their afterlife beliefs are similar to those of NDEs. He stated, "Ultimately, this study points to a type of single experiential 'reality,' which may or may not indicate a single transcendental reality" (Shushan, 2009, p. 199). Warren Jefferson (2008) has written about the NDEs of North American Indians and documented that many of their afterlife accounts include reincarnation experiences. Finally, Marianne Rankin (2008) has written an excellent overview of transpersonal experiences, including NDEs, entitled, An Introduction to Religious and Spiritual Experience. This work covers experiences in world religions, ancient and modern, East and West.

I have already discussed Osis and Haraldsson's (1977) wonderful comparison between Americans who were primarily Christian to East Indians who were primarily Hindu, but both authors were psychologists and not theologians. Some NDE researchers, including me, are not afraid to link findings from NDE research with their religious beliefs. These authors include Conservative Christians Maurice Rawlings (1978) and Michael Sabom (1998), Mormon Christian Craig Lundahl (1981), and Universalist Christians Ken Vincent (2003, 2005) and Kevin Williams (2002). 


\section{Conclusion}

The search for God and afterlife in the Age of Science highlights an overlooked aspect of the so-called conflict between religion and science. For the past 150 years, social and biomedical scientists have researched the very nature of religion itself using all the tools available to modern science. NDEs and other transpersonal experiences can be and are investigated in the same way all other psychological phenomena are investigated. The validity of these experiences is based on several data sources, including: (1) case studies of transpersonal experience (Bucke, 1901/1931, pp. 9-11, 287-289, 357-359; Guggenheim \& Guggenheim, 1996; Maxwell \& Schudin, 1990; Wiebe, 1997, pp. 40-88; 2000, pp. 119-141); (2) sociological surveys that reveal who and what percentage of the population have NDEs and other transpersonal experiences (Argyle, 2000, p. 56; Wood 1989, p. 856); (3) psychological assessment instruments that measure not only the mental health of the individual but also evaluate the depth of mystical experiences (Hood, 2001; Hood. Spilka, Hunsberger, \& Gorsuch, 1996, pp. 183-272), (4) biomedical and neuroscience testing, including the EEG, PET-scan, and functional MRI to, in some cases, document genuine altered states of consciousness and demonstrate that transpersonal experiences are not just wishful thinking (Hood et al., 1996, pp. 193-196; Newberg, D'Aquili, \& Rause, 2001; Wulff, 1997, pp. 169188) and EEGs and EKGs that enable the documentation of the dying process in NDEs that occur in hospitals; (5) sociological and psychological investigations that assess the aftereffects of these experiences (Greyson, 2000, pp. 319-320; 345; Hick, 1999, pp. 163170; Hood et al., 1996, pp. 410-411); and 6) controlled experimental research such as Pahnke's experiment on the effects of psychedelics (Argyle, 2000, pp. 64-66; Smith, 2000, pp. 199-205).

In my opinion, although the NDE and other transpersonal experiences do not prove the existence of a personal God and afterlife, they definitely point to it. Research to date documents the fact that: (1) a large percentage of the population has experienced NDEs and other transpersonal experiences, (2) the overwhelming majority of people who have NDEs and other transpersonal experiences are mentally healthy and not psychotic, and (3) NDEs and other transpersonal experiences change people's lives for the better. It also appears that NDEs and other transpersonal experiences represent phenomenological realities at the origin of virtually all the world's major religions. 


\section{References}

American Psychiatric Association. (1980). Diagnostic and statistical manual of mental disorders ( $3^{\text {rd }}$ ed.). Washington, DC: Author.

Antia, K. (2005). Zarathushti view of death and afterlife. FEZANA Journal, 3, 32-36, 55.

Argyle, M. (2000). Psychology and religion. New York, NY: Routledge.

Barrett, W. F. (1926). Death-bed visions. London, England: Methuen.

Basford, T. (1990). Near-death experiences: An annotated bibliography. New York, NY: Garland.

Becker, C. B. (1982). The failure of Saganomics: Why birth models cannot explain neardeath phenomena. Anabiosis - The Journal for Near-Death Studies, 2, 102-109.

Benson, H., \& Stark, M. (1997). Timeless healing: The power and biology of belief. New York, NY: Fireside.

Bentall, R. P. (2000). Hallucinatory experiences. In E. Cardeña, S. J. Lynn, \& S. Kripper (Eds.), Varieties of anomalous experience: Examining the scientific evidence (pp. 85-120). Washington, DC: American Psychological Association.

Blackmore, S. (1983). Birth and the OBE: An unhelpful analogy. Journal of the American Society for Psychical Research, 77, 227-238.

Borg, M. (1997). The God we never knew. San Francisco, CA: Harper San Francisco.

Bucke, R. M. (1931). Cosmic consciousness. New York, NY: E. F. Dutton. (Original work published 1901)

Cardeña, E., Lynn, S. J., Krippner, S. (Eds.). (2000). Introduction: Anomalous experiences in perspective. In E. Cardeña, S. J. Lynn, \& S. Krippner (Eds.), Varieties of anomalous experience: Examining the scientific evidence (pp. 3-21). Washington, DC: American Psychological Association.

Clarke, I. (Ed). (2001). Psychosis and spirituality. Philadelphia, PA: Whurr.

Cressy, J. (1994). The near-death experience: Mysticism or madness. Hanover, MA: Christopher.

Cressy, J. (1996). Mysticism and the near-death experience. In L. W. Bailey \& J. Yates (Eds.), The near-death experience: A reader (pp. 369-384). New York, NY: Routledge.

Daniels, M. (2004). Transpersonal psychologies. In C. Partridge (Ed.), New religions: A guide: New religious movements, sects, and alternative spiritualities. New York, NY: Oxford University Press.

Ellwood, G. F. (2001). The uttermost deep. New York, NY: Lantern Books.

Fenwick, P., \& Fenwick, E. (1995). The truth in the light. New York, NY: Berkley Books.

Fox, M. (2003). Religion, spirituality, and the near-death experience. New York, NY: Routledge.

Gregory the Great. (1959). Saint Gregory the Great, Dialogues (O. J. Zimmerman, Trans.). New York, NY: Fathers of the Church. (Original work published 6th century $\mathrm{AD})$

Greeley, A. (1974). Ecstasy: A way of knowing. Englewood Cliffs, NJ: Prentice Hall.

Greyson, B. (2000). Near-death experiences. In E. Cardeña, S. J. Lynn, \& S. Krippner (Eds.), Varieties of anomalous experience: Examining the scientific evidence (pp. 315-352). Washington, DC: American Psychological Association.

Greyson, B., \& Bush, N. E. (1992). Distressing near-death experiences. Psychiatry, 55, 95-109.

Greyson, B., Kelly, E. W., \& Kelly, E. F. (2009). Explanatory models for near-death experience. In J. Holden, B. Greyson, \& D. James (Eds.), The handbook of near-death experiences: Thirty years of investigation. Santa Barbara, CA: Praeger/ABC-CLIO.

Guggenheim, B., \& Guggenheim, J. (1996). Hello from heaven. New York, NY: Bantam.

Hardy, A. (1997). The spiritual nature of man. Oxford, England: The Religious Experience Research Centre. (Original work published 1979)

Harpur, T. (1991). Life after death. Toronto, Canada: McClelland \& Stewart. 
Hastings, A., Ferguson, E., Hutton, M., Goldman, A., Braud, W., Greene, E., ... Steinbach-Humphrey, S. (2002). Psychomanteum research: Experiences and effects on bereavement. Omega, 45, 211-228.

Hay, D. (1987). Exploring inner space: Scientists and religious experience. London, England: Mowbray.

Hick, J. (1993). Disputed questions in theology and the philosophy of religion. New Haven, CT: Yale University Press.

Hick, J. (1999). The fifth dimension. Oxford, England: One World.

Holden, J., Greyson, B., \& James, D. (Eds.). (2009). The handbook of near-death experiences: Thirty years of investigation. Santa Barbara, CA: Praeger/ABC-CLIO.

Holmes, H. (2006). Religious experiencing in contemporary China. De Numine, 40(2), $33-34$.

Hood, R. W. (2001). Dimensions of mystical experiences: Empirical studies and psychological links. New York, NY: Rodopi.

Hood, R. W., Spilka, B., Hunsberger, B., \& Gorsuch, C. R. (1996). The psychology of religion: An empirical approach ( $2^{\text {nd }}$ ed.). New York, NY: Guilford Press.

Horgan, J. (2003). Rational mysticism: Dispatches from the border between science and spirituality. New York, NY: Houghton Mifflin.

Hyslop, J. H. (1908). Psychical research and the resurrection. Boston, MA: Small, Maynard.

International Association for Near-Death Studies. (2009). History and founders. Retrieved from http://www.iands.org/about_iands/iands/history.html

James, W. (1994). The varieties of religious experience. New York, NY: Modern Library. (Original work published 1902)

Jefferson, W. (2008). Reincarnation beliefs of North American Indians, soul journeys, metamorphoses, and near-death experience. Summertown, TN: Native Voices.

Jung, C. G. (1961). Memories, dreams, reflections. New York, NY: Pantheon Press.

Keller, J. C. (2005). Swedish scientists can't replicate religious experience in lab. Retrieved from www.stnews.org/print.php?article_id:28

Kelly, E. F. (2007). Toward a psychology for the $21^{\text {st }}$ century. In E. F. Kelly, E. W. Kelly, A. Crabtree, A. Gauld, M. Grosso, \& B. Greyson, Irreducible mind: Toward a psychology for the $21^{\text {st }}$ century (pp. 577-643). New York, NY: Rowman \& Littlefield.

Kelly, E. W., Greyson, B., \& Kelly, E. F. (2007). Unusual experiences near-death and related phenomena. In E. F. Kelly, E. W. Kelly, A. Crabtree, A. Gauld, M. Grosso, \& B. Greyson, Irreducible mind: Toward a psychology for the $21^{\text {st }}$ century (pp. 577-643). New York, NY: Rowman \& Littlefield.

Kircher, P. M. (1995). Love is the link. Burdett, NY: Larson.

Kroll, J., \& Bachrach, B. (1982). Visions and psychopathology in the middle ages. Journal of Nervous and Mental Disease, 170, 41-49.

Leary, T. (1983). Flashbacks: An autobiography. Los Angeles, CA: Jeremy P. Tarcher.

Long, J., \& Perry, P. (2010). Evidence of the afterlife: The science of near-death experiences. New York, NY: Harper One.

Lundahl, C. R. (1981). The perceived other world in Mormon near-death experiences: A social and physical description. Omega, 12, 319-327.

Maslow, A. (1964). Religions, values, and peak-experiences. New York, NY: Viking Press.

Masumian, F. C. (1995). Life after death: A study of the afterlife in world religions. Oxford, England: One World.

Maxwell, M., \& Schudin, V. T. (1990). Seeing the invisible. London, England: Arkana.

Meyer, M. W. (Ed.). (1987). The ancient mysteries: A sourcebook. San Francisco, CA: Harper \& Row.

Mitofsky International and Edison Media Research. (2002, April 26). Special report: Exploring religious America. Religion \& Ethics Newsweekly. Retrieved from www.pbs. org/wnet/religionandethics/week534/specialreport.html

Moody, R. (1975). Life after life. Covington, GA: Mockingbird Books. 
Moody, R., \& Perry, P. (1993). Reunions: Visionary encounters with departed loved ones. New York, NY: Villard Books.

Müller, F. M.(Ed.). (1897). Sacred books of the East. Oxford, England: Oxford University Press.

Murphy, T. (2006). Innerworlds. Retrieved from: www.innerworld.50megs.com/

Myers, F. W. H. (1903). Human personality and its survival of bodily death. London, England: Longmans, Green.

Newberg, A., D'Aquili, E., \& Rause, V. (2001). Why God won't go away: Brain science and the biology of belief. New York, NY: Ballantine Books.

Nigosian, S. A. (2000). World religions: A historical approach ( ${ }^{\text {rd }}$ ed.). New York, NY: Bedford/St. Martin's.

Oakes, K., \& Gahlin, L. (2003). Ancient Egypt: An illustrated reference to the myths, religion, pyramids, and temples of the land of the pharaohs. New York, NY: Barnes \& Noble.

Osis, K., \& Haraldsson, E. (1977). At the hour of death. New York, NY: Avon Books,

Oxman, T. E., Rosenberg, S. D., Schnurr, P. P., Tucker, G. J., \& Gala, G. (1988). The language of altered states. Journal of Nervous and Mental Disease, 176, 401-408.

Partridge, C. (Ed.). (2004). New religions: A guide: New religious movements, sects, and alternative spiritualities. New York, NY: Oxford University Press.

Perry, M. C. (1959). The Easter enigma: An essay on the resurrection with specific reference to the data of psychical research. London, England: Faber \& Faber.

Plato. (1892). The dialogues of Plato (B. Jowett, Trans.). London, England: Humphrey Milford. (Original work published $4^{\text {th }}$ century BC)

Rankin, M. (2008). An introduction to religious and spiritual experience. London, England: Continuum International.

Rawlings, M. S. (1978). Beyond death's door. Nashville, TN: Thomas Nelson.

Ring, K. (1980). Life at death: A scientific investigation of the near-death experience. New York, NY: Coward, McCann, \& Geoghegan.

Ring, K. (1986). From alpha to omega: Ancient mysteries and the near-death experience. Anabiosis - The Journal for Near-Death Studies, 5, 3-15.

Ring, K. (2005). Letter to the editor: Scope of IANDS and the journal. Journal of NearDeath Studies, 24, 51-52.

Ring, K., \& Valarino, E. E. (1998). Lessons from the light: What we can learn from the near-death experience. New York, NY: Insight Books.

Roll, W. G. (2004). Psychomanteum research: A pilot study. Journal of Near-Death Studies, 22, 251-260.

Sabom, M. (1982). Recollections of death: A medical investigation. New York, NY: Harper \& Row.

Sabom, M. (1998). Light and death: One doctor's fascinating account of near-death experiences. Grand Rapids, MI: Zondervan.

Shushan, G. (2009). Conceptions of afterlife in early civilizations: Universalism, constructivism, and near-death experience. London, England: Continuum International.

Siglag, M. A. (1986). Schizophrenic and mystical experiences: Similarities and differences (Doctorial dissertation). Retrieved from ProQuest. (AAT 8706811)

Smith, H. (2000). Cleansing the doors of perception. New York, NY: Jeremy P. Tarcher/ Putnam.

Vincent, K. R. (1987). The full battery codebook: A handbook for psychological test interpretation for clinical, counseling, rehabilitation, and school psychology. Norwood, NJ: Ablex.

Vincent, K. R. (1994). Visions of God from the near death experience. Burdett, NY: Larson.

Vincent, K. R. (1999). The Magi: From Zoroaster to the "three wise men."North Richland Hills, TX: Bibal Press. 
Vincent, K. R. (2003). The near-death experience and Christian universalism. Journal of Near-Death Studies, 22, 57-71.

Vincent, K. R. (2005). The golden thread: God's promise of universal salvation. New York, NY: iUniverse.

Walker, B. A., \& Serdahley, W. J. (1990). Historical perspectives on near-death phenomena. Journal of Near-Death Studies, 9, 105-121.

Wiebe, P. H. (1997). Visions of Jesus. New York, NY: Oxford.

Wiebe, P. H. (2000). Critical reflections on Christian visions. Journal of Consciousness Studies, 7, 119-141.

Williams, K. R. (2002). Nothing better than death: Insights from sixty-two profound neardeath experiences. Philadelphia, PA: Xlibris.

Wood, F. W. (1989). An American profile — opinions and behavior 1972-1989. Chicago, IL: National Opinion Research Center.

Wood, S. E., \& Wood, E. G. (1996). The world of psychology ( $2^{\text {nd }}$ ed.). Boston, MA: Allyn \& Bacon.

Wulff, D. M. (1997). Psychology of religion ( $2^{\text {nd }}$ ed.). New York, NY: John Wiley \& Sons. Yao, X., \& Badham, P. (2007). Religious experience in contemporary China. Cardiff, Wales: University of Wales Press.

Zaleski, C. (1987). Otherworld journeys: Accounts of near-death experience in medieval and modern times. New York, NY: Oxford University Press. 